\title{
STUDI KASUS PERSONAL BRANDING KONTEN KREATOR PADA AKUN TWITTER@BROJABROOO
}

\author{
Dhanar Jabro Febiansah ${ }^{1}$, Sudono Syueb², Siska Armawati Sufa ${ }^{3}$, dan Eny Ratnasari* \\ 1,2Universitas Dr. Soetomo, Surabaya, Indonesia. \\ ${ }^{3,4}$ Universitas Padjadjaran, Bandung, Indonesia. \\ *eny12001@mail.unpad.ac.id
}

\begin{abstract}
Personal branding for a content creator is needed so that there are characteristics that are remembered by followers. The development of information technology also encourages the emergence of various social media that can be used as a means of forming personal content branding creators. This study aims to analyze the personal branding carried out by creator content in the social media account Twitter@brojabrooo. This research will try to illustrate clearly the process of managing personal branding in the@brojabrooo account using the case study method.As a content creator, Jabro has done personal branding to distinguish himself from other creator content. Researchers found 8 main concepts in building personal branding in accordance with what was stated by Peter Montoya (2002). Jabro built personal branding as a content creator via Twitter and fulfilled the 8 main concepts. This can be seen from Jabro's tweet that contains a variety of content, mostly dominated by photos and videos about him. Personal branding built by Jabro is a content creator who wants to entertain netizens and consistently use East Javanese.
\end{abstract}

Keywords: Content Creator, Personal Branding, Twitter

\begin{abstract}
Abstrak
Personal branding bagi seorang konten kreator dibutuhkan agar ada ciri khas yang diingat oleh pengikutnya. Perkembangan teknologi informasi juga mendorong munculnya berbagai media sosial yang dapat digunakan sebagai sarana membentuk personal branding konten kreator. Penelitian ini bertujuan untuk menganalisis personal branding yang dilakukan oleh konten kreator dalam akun media sosial Twitter@brojabrooo. Penelitian ini akan mencoba menggambarkan secara jelas tentang proses pengelolaan personal branding dalam akun@brojabrooo dengan menggunakan metode studi kasus.Sebagai seorang konten kreator, Jabro telah melakukan personal branding agar membedakan dirinya dengan konten kreator lainnya. Peneliti menemukan 8 konsep utama dalam membangun personal branding sesuai dengan apa yang dikemukakan oleh Peter Montoya (2002). Jabro membangun personal branding sebagai seorang konten kreator melalui Twitter dan memenuhi 8 konsep utama tersebut. Hal tersebut terlihat dari cuitan Jabro yang berisikan berbagai macam konten yang sebagian besar didominasi oleh foto dan video tentang dirinya. Personal branding yang dibangun oleh Jabro adalah seorang konten kreator yang ingin menghibur netizen dan konsisten menggunakan Bahasa Jawa Timuran.
\end{abstract}

Kata Kunci: Konten Kreator, Personal Branding, Twitter

\section{PENDAHULUAN}

Dhanar Jabro Febiansah adalah seorang konten kreator yang mencuri perhatian saat adanya aksi demo mahasiswa tentang RUU KPK yang berada di depan Gedung DPRD Kota Surabaya pada September 2019. Jabro mengenakan sayap berwarna hitam saat aksi demo tersebut berlangsung sehingga menjadi sorotan peserta demo lainnya. Aksi tersebut diunggah dalam media sosial Instagram miliknya@brojabrooo dan kemudian viral di media sosial. Ungguhan tersebut menjadikan Jabro mendapat julukan "Mahasiswa Bersayap".

Seperti yang terlihat dalam tangkapan layar 
pada gambar 1, Jabro mengenakan sayap sebagai parodi dari lagu Ariana Grande yang berjudul Don't Call Me Angel. Aksi Jabro tersebut justru mengesankan bahwa dirinya seperti Angels dalam peragaan busana Victoria Secret.Aksi Jabro dengan sayap kecil berwarna hitam atau sang bidadari pada aksi Surabaya Menggugat menjadi viral di Twitter. Hal ini terjadi lantaran aksilenggak-lenggok di jalanan saat demo berlangsung menjadi viral karena diunggah oleh akun@taufikNIC di Twitter. Kemudian unggahan berhasil meraih 677 ribu tayang retweet, lebih dari 8.500 likes serta 696 komentar.

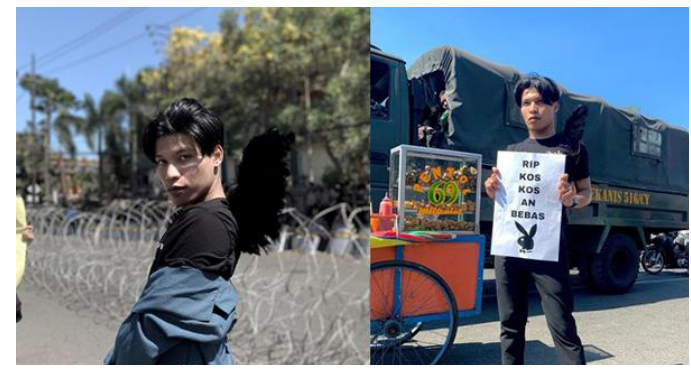

Gambar 1. Unggahan akun@taufikNIC yang melambungkan nama Jabro

(Sumber: twitter.com, 2020)

Jabro melakukan beberapa strategi personal branding agar berbeda dengan konten kreator lainnya. Personal branding yang Ia bangun pada media sosial Twitter adalah sebagai seorang konten kreator yang humoris. Dilahirkan sebagai orang dengan suku Jawa, Jabro juga memanfaatkan peluang tersebut untuk membuat konten dengan menggunakan Bahasa Jawa. Hal ini pun menjadi kekuatan sehingga dapat memperkuat personal branding Jabro.

Pembentukan personal branding dengan mengangkat budaya Jawa telah terlebih dahulu dilakukan oleh Bayu Eko Moektito melalui video blog atau vlog. Bayu berhasil disukai oleh masyarakat karena vlog Bayu yang selalu konsisten bernuansa Jawa dikemas dengan menarik, kreatif, dan menghibur (Yusuf, 2019).

Banyaknya konten kreator yang bermunculan di Twitter membuat mereka saling beradu ide untuk menciptakan konten. Pada dasarnya setiap selebriti Twitter memiliki brand tersendiri sesuai dengan karakteristik dan kompetensi dan kompetensi yang dimilikinya. Salah satunya adalah Dhanar Jabro Febiansah atau yang lebh dikenal dengan Jabro dengan akun nama akun Twitter@brojabrooo. Dalam akun media sosialnya, Jabro sering mengunggah video singkat. Video singkat tersebut sengaja diunggah di media sosial khususnya Twitter. Perlu diketahui rata-rata waktu penayangan video terutama pada perangkat seluler telah berkembang lebih dari 200 jam setahun sejak tahun 2012 (Vollmer, 2017). Hal ini sekaligus memperlihatkan dampak dari kebiasaan mengkonsumsi video yang berubah menjadi bersifat mobile dan personalized (We Are Social, 2017).

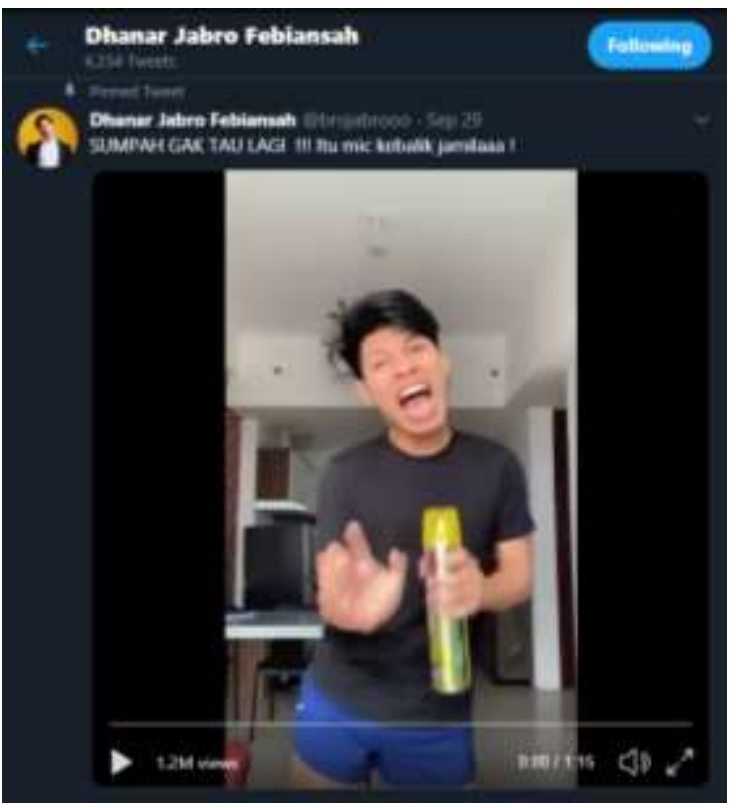

Gambar 2. Video Unggahan dalam Akun Twitter@ brojabrooo yang Paling Banyak Ditonton

(Sumber: twitter.com, 2020)

Melalui akun@brojabrooo, Jabro menunjukkan eksistensinya sebagai seorang konten kreator kepada pengikutnya. Adapun video yang Ia bagikan pada pengikutnya diantaranya adalah video lipsync, video parodi, dan video parodi mengenai logat yang ada di Surabaya. Video yang paling menyita perhatian adalah video lypsinc lagu Agnes Monica yang 
diunggah pada 29 September 2019 (Gambar 2). Video tersebut telah ditonton oleh lebih dari 1,2 juta pengguna, 21.700 Retweets, dan mendapat 29.200 Likes. Video dengan durasi 1 menit 15 detik ini lengkap dengan cuitan dari Jabro yang tertulis "SUMPAH GAK TAU LAGI !!! Itu mic kebalik jamilaaa !". Video ini pun mendapat berbagai tanggapan dari warga net.

Branding dapat diartikan sebagai upaya untuk membuat atau membangun brand atau merek yang dapat dilakukan oleh siapa saja untuk produk apapun, seperti yang diklaim oleh Terence (Shimp, 2004:7). Brand juga didefinisikan sebagai "value indicator" yaitu indikator yang menggambarkan seberapa kokoh dan solid-nya nilai yang ditawarkan kepada pelanggan (Hermawan, 2008).

Dalam melakukan personal branding di media sosial, sangatlah penting untuk melibatkan pikiran dan perasaan orang lain agar terkait erat dengan personal branding seseorang. Ketika sebuah personal branding dapat membangun sebuah hubungan yang erat dengan pikiran dan perasaan orang lain, maka itulah personal branding yang mempunyai kekuatan sesungguhnya (McNally \& Speak, 2004:14). Dalam membangun sebuah brand dibutuhkan media atau saluran yang dapat dijadikan sarana informasi pembentukan personal branding. Personal branding apabila dikombinasikan dengan sarana yang hebat dan tepat, akan memunculkan kinerja puncak dan menciptakan dasar yang stabil bagi keandalan, kredibilitas, dan kharisma diri. Seseorang harus bisa memilih dan membuat target pasar yang sangat jelas bagi pesan personal branding-nya. Selain itu, seseorang yang hendak membentuk personal branding harus memiliki saluran yang tepat untuk mengkomunikasikan personal branding-nya (Rampersad, 2008).

Dalam upaya membangun personal branding pada media sosial, seorang figur publik seperti pebisnis atau enterpreneur tidak aktif mengunggah pada semua media sosial. Mereka cenderung memilih media sosial tertentu untuk melakukan personal branding.
(Rachmawati \& Nurhajati, 2019). Disamping itu, personal branding yang dilakukan youtuber game Michael Souw dengan membuat konten video yang menunjukkan ciri khasnya agar berbeda dengan youtuber game lainnya supaya pengikutnya tidak merasa bosan. Michael Souw bahkan menjalin hubungan baik dengan pengikutnya dengan melakukan giveaway (Wibowo \& Rusdi, 2019). Dalam penggunaan media sosial Twitter, Kaesang Pangarep melalui akun@kaesangp berhasil membangun personal branding sebagai seorang pebisnis (penjual pisang) dan bukan sebagai seorang anak presiden (Narida, 2019).

Konten kreator memahami pentingnya membangun brand bagi perjalanan karir mereka. Berbagai cara dan strategi pun dilakukan untuk membangun image yang baik dimata publik. Hal ini juga dilakukan oleh Jabro dalam akun Twitter@brojabrooo. Citra yang ditampilkan Jabro dalam akun media sosial Twitter tersebut dapat disebut dengan personal branding. Personal branding merupakan identitas pribadi yang mampu menciptakan sebuah respon emosional terhadap orang lain mengenai kualitas dan nilai yang dimiliki orang tersebut. Untuk mendapatkan personal brand yang impresif dibutuhkan personal branding yang kuat.

Penelitianinidimaksudkanuntukmengetahui bagaimana Twitter dapat menjadi media pendukung pembentukan personal branding dari Jabro. Peneliti ingin menggambarkan bagaimana percakapan yang ada pada media sosial Twitter tentang@brojabrooo. Terdapat beberapa aspek yang dijadikan pertanyaan utama dalam penelitian ini serta akan mencari penjelasan tentang fenomena tersebut. Oleh sebab itu, penelitian ini akan berfokus pada personal branding seorang konten kreator dengan memanfaatkan media sosial Twitter.

\section{METODOLOGI}

Penelitian ini adalah penelitian kualitatif dengan pendekatan studi kasus. Penelitian kualitatif merupakan penelitian yang 
melibatkan analisis data dalam bentuk deskripsi dan data tidak dapat diukur secara langsung. Berdasarkan unit analisis dalam penelitian ini, sumber data dalam penelitian adalah individu. Hal ini dikarenakan sumber data yang didapat adalah dari data Twitter secara personal di media sosial.

Peneliti ingin memperlihatkan bagaimana konten yang diunggah dalam media sosial Twitter dapat digunakan sebagai salah satu cara dalam membentuk personal branding. Oleh karenaitu, penelitimenggunakan studikasus dari konten kreator@brojabrooo. Alasan pemilihan @brojabroo sebagai contoh kasus adalah sebagai berikut: (1)@brojabrooo merupakan konten kreator yang sedang naik daun; (2)@ brojabrooo dapat dikatakan cukup populer di media sosial Twitter; (3)@brojabrooo juga dinilai memiliki ciri personal branding yang menjadi keunikan tersendiri yang membedakan dirinya dengan konten kreator lainnya. Konten Jabro digemari oleh berbagai kalangan terutama remaja dan dewasa muda karena konten yang lucu dan gaya yang ceplas-ceplos saat berbicara. Konten yang membuatnya viral di media sosial diantaranya adalah video lipsync dengan menggunakan semprotan nyamuk dan mendapat julukan bidadari bersayap yang hampir menabrak gerobak penjual cilok ketika ada aksi demonstrasi di depan kantor DPRD Kota Surabaya.

Populasi penelitian ini adalah tweet yang dibuat oleh Jabro melalui akun twitternya @ brojabrooo periode September 2019 sampai dengan Februari 2020 yang terdapat elemen ataupun konsep dasar dari membangun personal branding. Dasar pertimbangan peneliti memilih periode tersebut adalah sedang ramai pembicaraan tentang@brojabroo terkait video parodinya. Dalam penelitian ini, penulis mengunakan teknik purposive sampling. Dalam penelitian ini, peneliti tidak melakukan kontrol dan tidak memanipulasi variabel penelitian. dari penelitian ini adalah seluruh tweet yang memuat kata@brojabrooo. Sampel dari penelitian ini adalah tweet yang berupa interaksi dapat berupa mention, reply, ReTweet, maupun quote ReTweet kepada@ brojabrooo yang dicatat dalam batasan waktu pengamatan September 2019 hingga Februari 2020. Analisis data yang digunakan adalah (1) reduksi data, (2) display data, (3) mengambil kesimpulan dan verifikasi (Nasution, 2002).

\section{HASIL DAN PEMBAHASAN}

Twitter merupakan media sosial yang memungkinkan seorang konten kreator untuk melakukan interaksi yang bersifat cepat dengan orang yang dikehendakinya. Sifat Twitter yang real time, membuat Twitter menjadi media sosial yang sangat digandrungi para netizen dalam bersosialisasi.

Alasan memilih Twitter bagi seorang konten kreator seperti Jabro karena injeksinya lebih cepat di Twitter. Jabro menjelaskan alasannya menggunakan Twitter "Di Twitter lebih cepat. Kalau ada yang nge-retweet di Twitter, video bisa menjangkau orang lain. Beda kalau di Instagram yang nggak terlalu luas jangkauannya."

Adapun Jabro melakukan perbedaan antara konten yang Ia bagikan di Twitter dan Instagram. Dalam Twitter, Jabro dapat lebih bebas dibandingkan Twitter. Di Instagram, Jabro lebih berhati-hati dan sadar karena dalam media sosial tersebut dirinya lebih menjual sehingga dirinya sangat berhati-hati ketika mengunggah sesuatu.

Jabro menandaskan, "Kalau konten kreator lain Jabro hanya fokus pada Instagram saja, sedangkan akun@brojabrooo ingin fokus pada Instagram dan Twitter."

Bagi konten kreator seperti Jabro, interaksi dalam Twitter dilakukan untuk mendekatkan dirinya kepada followers. Hal ini dimaksudkan agar personal branding yang dilakukannya lebih dikenal banyak orang. Disamping itu, interaksi yang dilakukan hanya sebatas membalas komentar yang ada dalam tweetnya. Membalas komentar tersebut juga dilakukan secara acak. 
Akun@brojabrooo melakukan riset sendiri untuk mengetahui karakteristik dari followersnya. Hasil riset tersebut menyebutkan bahwa followersnya menyukai apabila Ia juga menyertakan video dalam cuitannya.

\section{Proses Pembentukan Personal Brand Melalui Twitter}

Proses pembentukan personal brand yang dilakukanoleh akun@brojabrooo sesuai seperti yang dikonsepkan oleh Peter Montoya. Peter Montoya mengungkapkan delapan konsep yang menjadi rumusan personal branding (Montoya, 2002). Delapan konsep tersebut adalah spesialisasi (law of specialization), kepemimpinan (law of leadership), kepribadian (law of personality), perbedaan (law of distinctiveness), kenampakan (law of visibility), kesatuan (law of unity), keteguhan (law of persistence), dan nama baik (law of goodwill). Analisis personal branding seorang konten kreator dalam akun Twitter@brojabrooo adalah sebagai berikut.

\section{The Law of Specialization (Spesialisasi)}

Personal branding memerlukan kekuatan, kelebihan, dan pencapaian tertentu. Oleh karena itu, seseorang harus mengetahui betul manakah yang merupakan kelebihannya. Spesialisasi merupakan kelebihan atau kemampuan khusus yang akan menarik khalayak dan akan membuat kita dipandang ahli dalam sebuah bidang. Jabro identik dengan konten yang mengundang gelak tawa. Dalam mengunggah cuitan dalam Twitter, Jabro seringkali memberikan video dan cuitan yang kocak dan membuat followersnya tertawa.

Dalam The Law of Specialization terdapat tujuh cara dalam membangun personal branding yaitu ability, behavior, lifestyle, mission, product, profession, dan service. Berikut ini adalah penjelasan lebih lanjut mengenai ketujuh cara The Law of Specialization yang telah dilakukan oleh akunTwitter@brojabrooo.
Ability

Melalui akun Twitter@brojabrooo, Ia berusaha untuk memperkenalkan dirinya melalui media microblogging Twitter sebagai seorang konten kreator yang memiliki selera humor yang tinggi. Hal ini terlihat dari berbagai isi tweet yang Ia sampaikan. Tweet pada gambar 3. adalah tweet yang membuat akun ini naik daun. Cuitan ini dilengkapi dengan sebuah video parodi lypsinc lagu Agnes Monica. Dalam tangkapan layar ini, Jabro menuliskan "SUMPAH GAK TAU LAGI !!! Itu mic kebalik jamilaaa !" Cuitan tersebut menggambarkan bahwa Jabro ingin menunjukkan bahwa dirinya mengangkat sisi humor dari video parodi lypsinc yang Ia buat. Melalui cuitan tersebut, Jabro ingin followers maupun viewers video ini menertawakan apa yang dia lakukan dan fokus pada botol pembasmi nyamuk yang Ia gunakan seolah sebagai mikrofon.

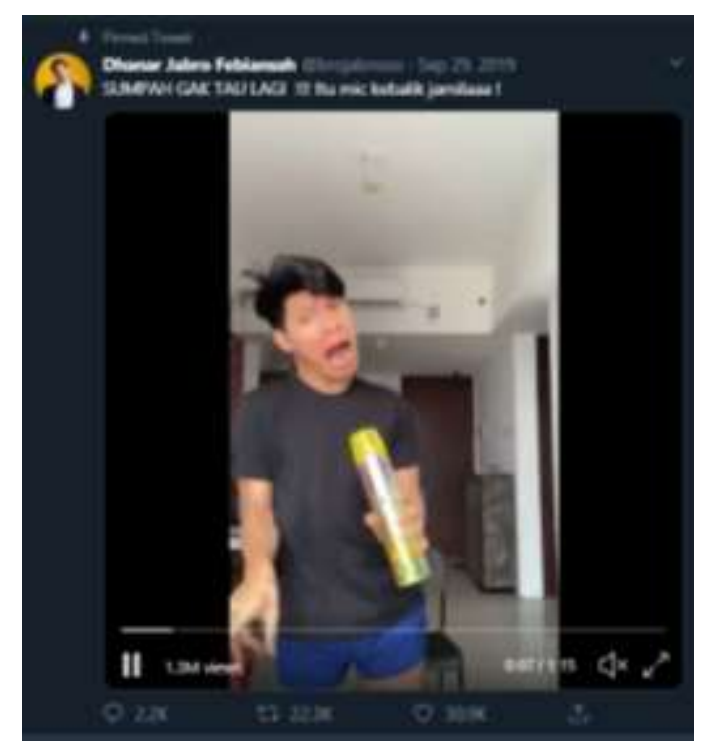

Gambar 3. Tangkapan Layar Tweet@brojabrooo pada 29 September 2019

(Sumber: twitter.com, 2020)

Hasil penelitian yang dilakukan oleh peneliti menunjukkan bahwa respon terhadap video lypsinc pada gambar 3 sangat tinggi. Video ini telah ditonton lebih dari 1.300.000 akun. Sampai dengan 16 Februari 2020, lebih dari 2.200 akun membalas cuitan tersebut. Sebanyak lebih dari 22.300 akun melakukan pengunggahan ulang 
(retweets) dan lebih dari 30.900 akun menyukai unggahan tersebut. Jabro pun memutuskan untuk menandai unggahan (pinned) ini dalam beranda Twitternya.

Adapun keahlian lainnya yang ditampilkan Jabro dalam akun Twitter @brojabrooo dalam video parodi yang dibuatnya adalah kepiawaiannya dalam menari dan menirukan artis aslinya. Gambar 4 adalah hasil tangkapan layar cuitan Jabro yang menirukan gaya Lisa Blackpink dalam sebuah video klip. Dari gaya hingga gerak gerik dalam video klip, Jabro tirukan persis dengan aslinya. Jabro juga menuliskan "Artis asli. Udah gausah komen." Video ini ditonton sebanyak lebih dari 104.100 akun, dengan 797 kali retweets, dan disukai lebih dari 2.600 akun.

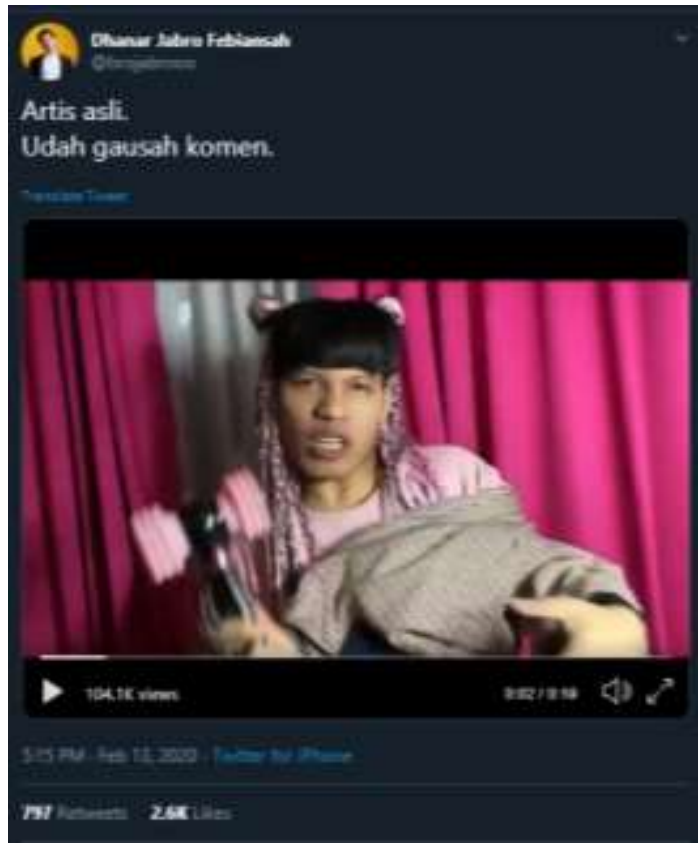

Gambar 4. Tangkapan Layar Tweet @brojabrooo pada 13 Februari 2020

(Sumber: twitter.com, 2020)

Gambar 5 adalah hasil tangkapan layar tweet@brojabrooo yang bertuliskan "Hanya anak yang berhati mulia yang dapat melihat ibu peri". Tweet ini dilengkapi dengan sebuah video parodi dari adegan sinetron Bidadari yang sempat hits pada awal tahun 2000-an. Video dalam tweet ini telah ditonton lebih dari
40.900 akun, dengan 107 balasan, 304 retweets, dan 1.000 likes.

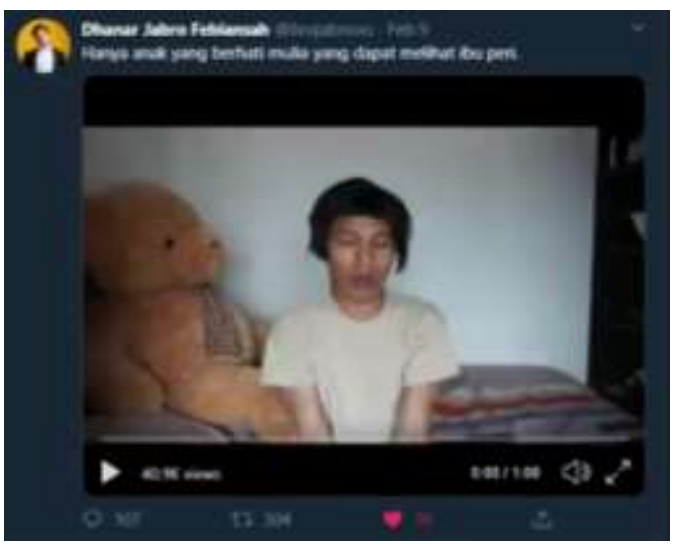

Gambar 5. Tangkapan Layar Tweet@brojabrooo pada 9 Februari 2020

(Sumber: twitter.com, 2020)

Peneliti menemukan beberapa tweet pada periode September 2019 hingga Februari 2020 yang di-posting oleh Jabro sebagai upaya membangun personal branding dengan cara menunjukkan keahliannya. Keahlian menonjol yang ingin ditampilkan adalah menunjukkan dirinya sebagai seorang konten kreator yang humoris dengan didukung kemampuannya membuat video parodi dan receh. Hal ini tentunya menunjukkan bahwa Jabro berupaya membangun personal branding dengan cara the law of specialization dalam bentuk ability.

\section{Behavior}

Jabro membuat tweet yang bertemakan tentang berbagai macam hal. Diantaranya adalah tweet yang lucu dan ceplas-ceplos yang tak jarang menggunakan Bahasa Jawa Timuran. Jabro juga sering menambahkan video dalam tweet yang diunggahnya untuk menarik perhatian followers. Tweet yang dilengkapi dengan video kemudian menarik komentar, like, atau tweet balasan dari warga net. Sepanjang September 2019 hingga Februari 2020, kebiasaan yang ditampilkan oleh Jabro dalam akunTwitter@brojabrooo pada gambar 6 berikut. 


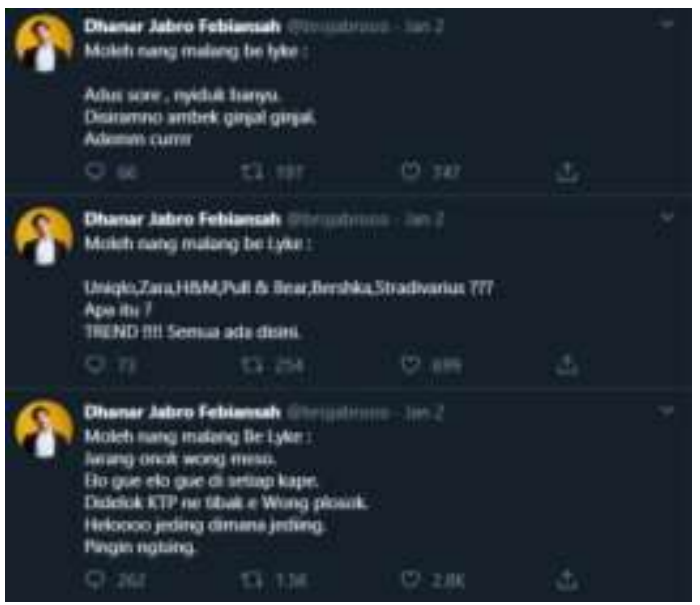

Gambar 6. Tangkapan Layar Tweet@brojabrooo pada 2 Januari 2020

(Sumber: twitter.com, 2020)

Dalam gambar 6 terlihat bahwa akun@ brojabrooo ingin menggambarkan tentang kebiasaannya ketika pulang ke rumah. Dengan menggunakan Bahasa Jawa dengan dialek Jawa Timuran yang dicampur dengan Bahasa Inggris slang, Ia menarik perhatian netizen di Twitter. Ketiga cuitan yang berurutan tersebut berisikan tentang kebiasaan yang dilakukan Jabro ketika di Kota Malang. Mulai dari dinginnya air di Malang, beberapa merk pakaian yang juga tersedia di pusat perbelanjaan di Malang, dan kebiasaan warga Malang.

\section{Lifestyle}

Melalui media microblogging seperti Twitter, Jabro menggambarkan bahwa dirinya adalah seorang anak muda yang suka menggunakan Bahasa Jawa dengan dialek Jawa Timuran dalam setiap kesempatan. Hal ini terlihat dalam beberapa tweet yang diunggah. Upaya akun@brojabrooo dalam membentuk personal branding sebagai seorang anak muda yang mencintai Bahasa Jawa menunjukkan bahwa terdapat the law of specialization dalambentuk lifestyle.

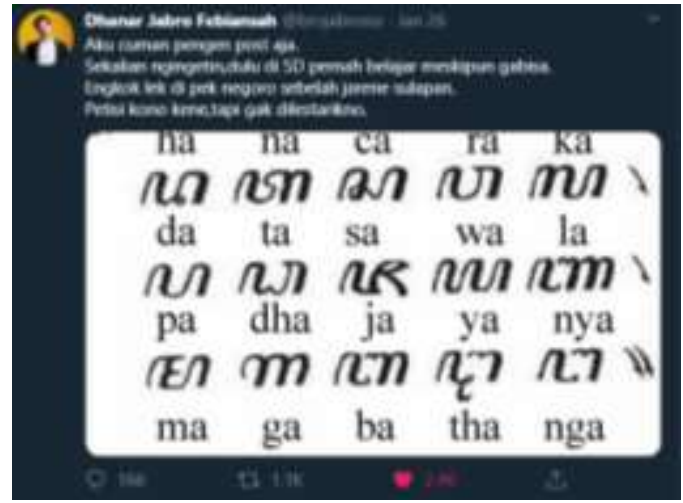

Gambar 7. Tangkapan Layar Tweet @brojabrooo pada 26 Januari 2020

(Sumber: twitter.com, 2020)

\section{Mission}

Dalam berbagai cuitan yang dibuat oleh Jabro, Ia konsisten untuk menampilkan bahwa dirinya adalah seorang konten kreator. Melalui tweet yang dilengkapi dengan video dan foto, Jabro berupaya untuk membangun personal branding bahwa dirinya bukan hanya seorang konten kreator seperti pada umumnya. Ia juga berkolaborasi dengan konten kreator lain untuk menyampaikan pesan positif.

Gambar 8 dan 9 adalah hasil tangkapan layar dari cuitan Jabro yang menyertakan sebuah video. Video ini merupakan hasil kolaborasi antara Jabro dengan konten kreator asal Surabaya Dono Pradana. Dalam video ini, Jabro dan Dono melakukan eksperimen sosial dengan menegur warga Surabaya yang melakukan pelanggaran lalu lintas.

Bertempat di depan perempatan Kebun Bibit di Bratang, Surabaya, Jabro dan Dono beraksi. Keduanya berulang kali mengingatkan para pengendara yang berhenti di zebra cross. "Ayo Mas mundur jangan di zebra cross, itu buat pejalan kaki," demikianlah ujar Dono dalam video konten.

Apabila terdapat pengendara yang tidak menurut kata mereka, Jabro pun menghampiri pengendara dan melakukan sesuatu. Seperti pengendara yang tidak memakai helm dengan benar, Jabro memasangkan helm dengan benar. Adapula pengendara yang tidak mau mundur 
dari zebra cross, Jabro kemudian membonceng di kursi belakang pengendara tersebut. Pengendara kemudian kesal dan membawa Jabro ikut dengan dirinya.

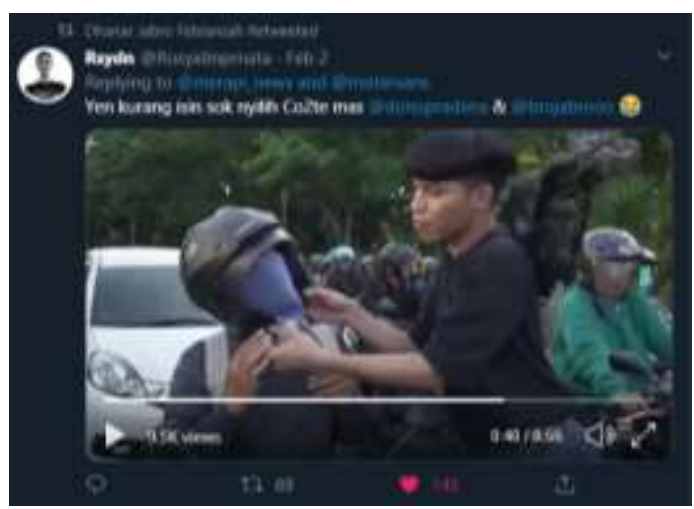

Gambar 8. Tangkapan Layar Tweet @brojabrooo pada 2 Februari 2020

(Sumber: twitter.com, 2020)

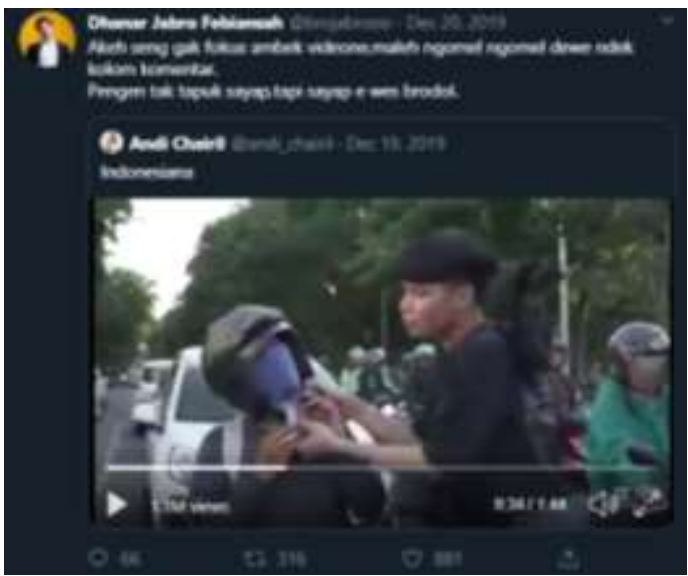

Gambar 9. Tangkapan Layar Tweet @brojabrooo pada 20 Desember 2019

(Sumber: twitter.com, 2020)

Dalam periode September 2019 hingga Februari 2020, terdapat lebih dari 10 cuitan yang dibuat oleh Jabro dan berisi tentang pesan positif untuk followersnya Melalui cuitan yang dibuat tersebut, Jabro tidak hanya sekedar mempromosikan dirinya melalui informasi serta pesan. Ia juga membangun personal branding bahwa dirinya adalah seorang konten kretaor yang menyebarkan konten positif terhadap khalayaknya. Hal ini termasuk dalam bagian the law of specialization dalam bentuk mission.

\section{Product}

Keunikan Jabro sebagai seorang konten kreator adalah dengan menunjukkan spesialisasi dirinya. Dalam kurun waktu September 2019 hingga Februari 2020 setiap minggunya Jabro mengunggah sedikitnya satu cuitan dan dilengkapi dengan video parodi yang merupakan kekhasan Jabro.

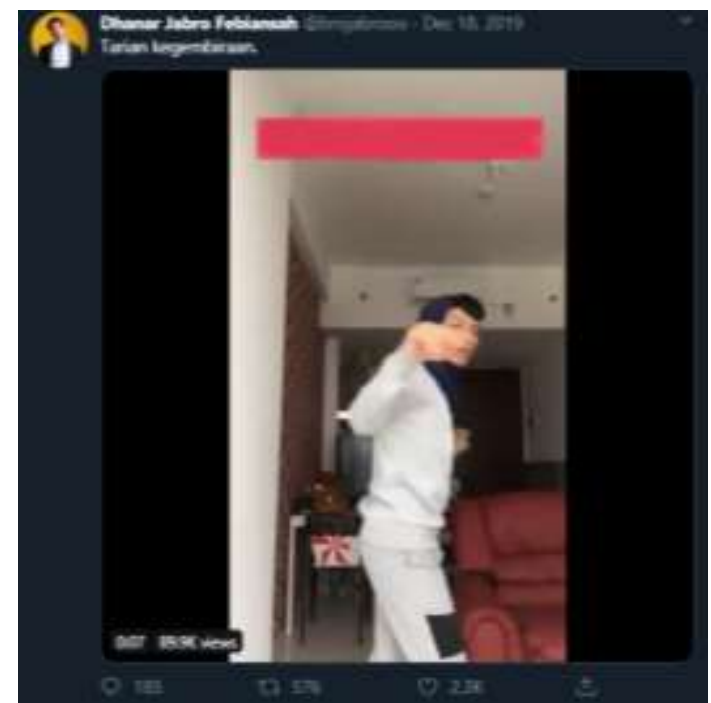

Gambar 10. Tangkapan Layar Tweet@brojabrooo pada 18 Desember 2019

(Sumber: twitter.com, 2020)

\section{Profession}

Spesialisasi profesi sebagai bentuk dari the law of specialization yang ditunjukkan Jabro sebagai upaya membangun personal branding dirinya sebagai seorang yang profesional dalam menjadi konten kreator. Diantaranya adalah dengan ditunjukkan dalam salah satu tweet yang berisi tentang suka duka menjadi seorang konten kreator.

Dalam cuitan pada gambar 11, Jabro menuliskan,

"Tweetku kena copyriht. Wait? Guys please, tujuanku post di tweet ya cuman sekedar menghibur. Mau viewersku jujuta juratur julekno wong e, aku juga ga dapat keuntungan 
sama sekali. Mau ngehibur lewat tulisan juga ga jago. Ah mulai skrg males deh nongol di $T L$. Sekian aku pamit."

Tetap dengan gaya khas Jabro yang selalu berusaha untuk memadukan denga humor, dalam cuitan tersebut terdapat keluh kesahnya sebagai konten kreator pada followers-nya.

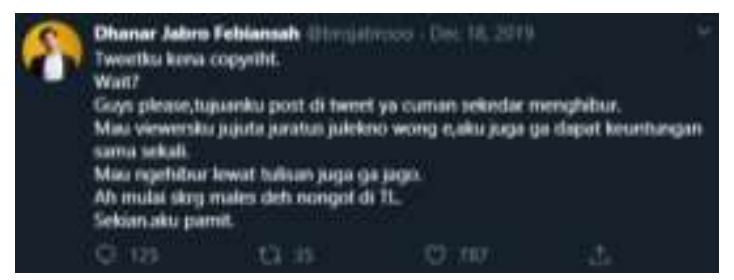

Gambar 11.Tangkapan Layar Tweet @ brojabrooo pada 18 Desember 2019

(Sumber: twitter.com, 2020)

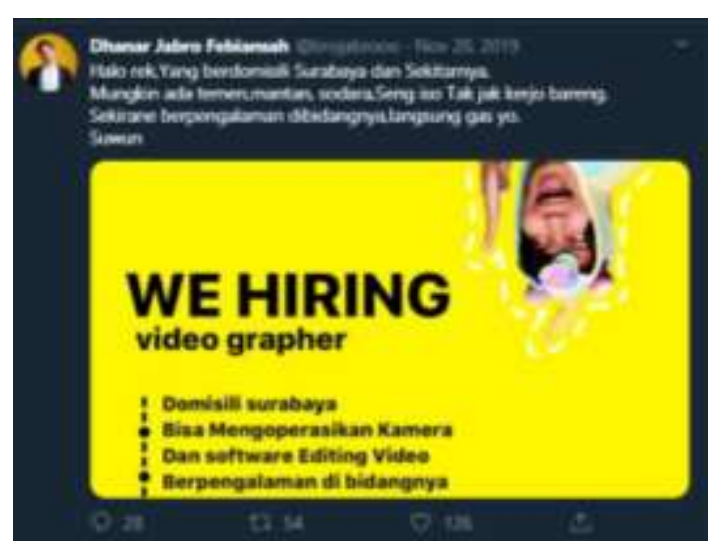

Gambar 12. Tangkapan Layar Tweet@brojabrooo pada 20 November 2019

(Sumber: twitter.com, 2020)

Sebagai seorang konten kreator yang profesional, Jabro tidak memungkiri bahwa dirinya membutuhkan bantuan profesional lainnya. Gambar 12 adalah sebuah lowongan pekerjaan sebagai videographer untuk membantu Jabro dalam aktivitas sebagai seorang konten kreator.

\section{Service}

The Law of Specialization dalam bentuk spesialisasi layanan atau servis ditunjukkan oleh Jabro dengan membalas tweet dari followers maupun dari warga net. Jabro juga tidak segan untuk melakukan retweet dari followers dirinya. Gambar 13 berikut adalah contoh interaksi Jabro dengan followers-nya di Twitter. Jabro tetap konsisten menggunakan Bahasa Jawa dengan dialek Jawa Timuran untuk membalas komentar dari followers.

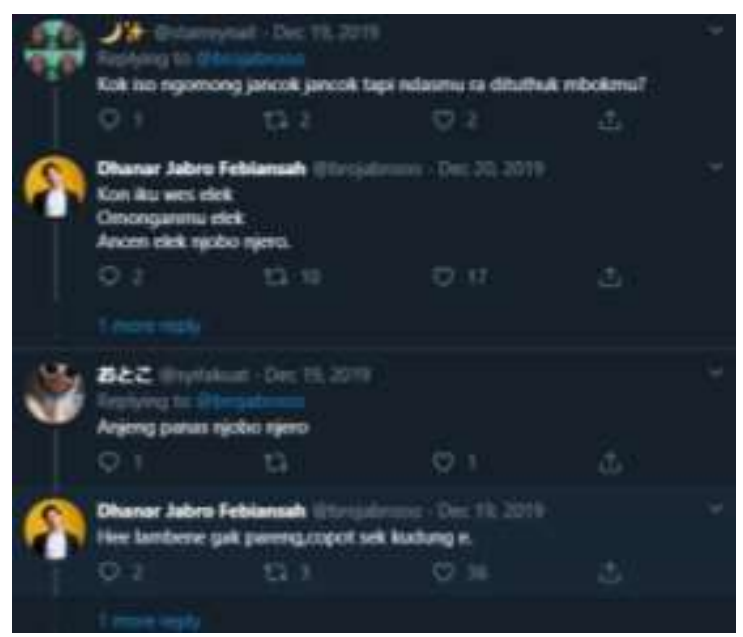

Gambar 13. Tangkapan Layar Tweet@brojabrooo pada 19 Desember 2019

(Sumber: twitter.com, 2020)

\section{The Law of Leadership (Kepemimpinan)}

Cuitan Jabro memposisikan dirinya sebagai pemimpin dari konten kreator lainnya. Hal ini terlihat dalam tweet akun@brojabrooo tentang inovasi yang dilakukannya sebagai seorang konten kreator. Inovasi tersebut ditunjukkan dengan adanya cuitan mengenai rencana Jabro untuk membuat Podcast Bincang Bersama Brojabrooo. Perlu diketahui bahwa tidak semua konten kreator berinovasi untuk membuat podcast.

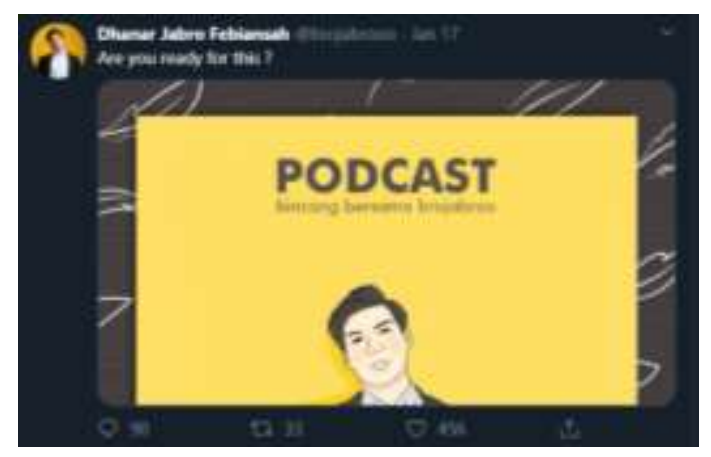

Gambar 14. Tangkapan Layar Tweet@brojabrooo pada 17 Januari 2020

(Sumber: twitter.com, 2020) 


\section{The Law of Personality (Kepribadian)}

The law of personality yang terdapat dalam tweet Jabro adalah Ia menggambarkan bahwa dirinya merupakan seseorang yang ceria dan menyukai humor. Hal ini terlihat dalam cuitan dengan konten humor yang sekaligus menggambarkan kehidupannya sehari-hari. Berdasarkan pengamatan, sepanjang September 2019 hingga Januari 2020, hampir seluruh cuitan Jabro dibumbui dengan humor. Hal ini mengindikasikan bahwa Jabro menggambarkan dirinya sebagai konten kreator yang lucu.

Jabro menjelaskan tentang alasan dirinya membuat citra diri konten kreator yang lucu. "Saya senang ketika bisa membuat orang lain terhibur dan tertawa. Terus konten yang lucu itu lebih menyenangkan buat followers. Followers juga lebih senang sama konten humor, mereka lebih tertarik untuk lihat yang lucu-lucu daripada yang serius," terangnya.

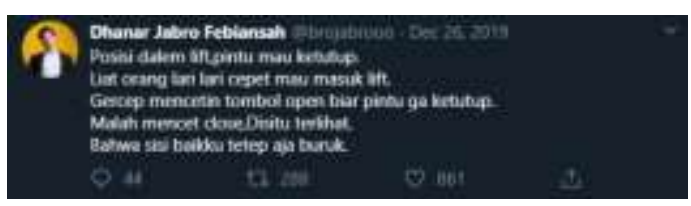

Gambar 15. Tangkapan Layar Tweet@brojabrooo pada 26 Desember 2019

(Sumber: twitter.com, 2020)

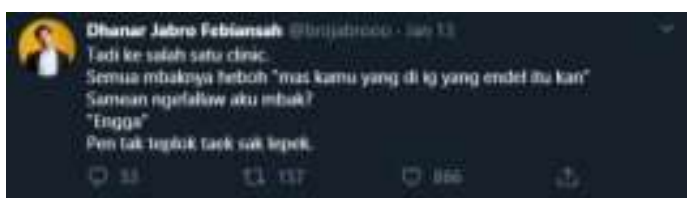

Gambar 16. Tangkapan Layar Tweet@brojabrooo pada 13 Januari 2020

(Sumber: twitter.com, 2020)

Dalam gambar 15, Jabro menuliskan bahwa dirinya ingin berbuat baik pada orang lain. Akan tetapi, ketika ingin berbuat baik justru Jabro melakukan kecerobohan. Cerita kecerobohan ini kemudian dibuat cuitan dan disukai sebanyal 861 oleh pengguna Twitter. Kemudian pada gambar 16, Jabro menunjukkan dirinya yang ceplas-ceplos dalam memberikan umpatan kepada seseorang dan berhasil membuat followersnya tertawa. Dengan menggunakan Bahasa Jawa Timuran,
Jabro memberikan umpatan kepada karyawan yang ada pada klinik.

Gambar17,akun@brojabrooomendapatkan tanggapan cukup tinggi dari warga net. Seperti yang terlihat dalam gambar tersebut, Jabro membuat konten dengan membandingkan foto dirinya dengan aktor yang sedang digandrungi yakni Jefri Nichol, tidak lupa dilengkapi dengan cuitan "Ah jauh beda perasaan." Cuitan ini pun mendapat respon sebanyak 323 balasan, 277 retweets, dan 2.300 likes.

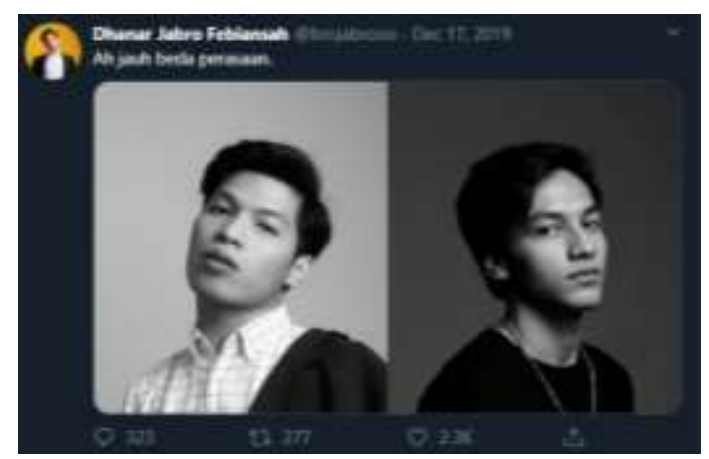

Gambar 17. Tangkapan Layar Tweet@brojabrooo pada 17 Desember 2019

(Sumber: twitter.com, 2020)

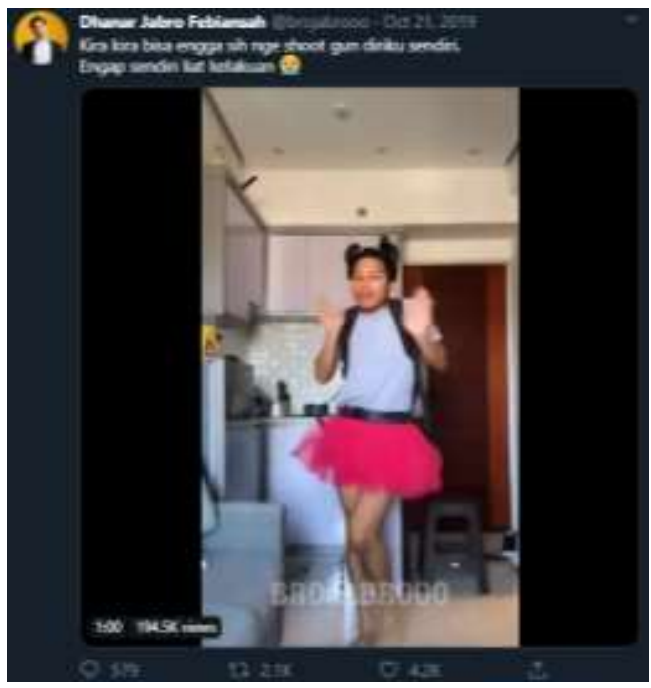

Gambar 18. Tangkapan Layar Tweet@brojabrooo pada 21 Oktober 2019

(Sumber: twitter.com, 2020)

Adapun gambar 18, dengan cuitan "Kira kira bisa engga sih nge shoot gun diriku sendiri. Engap sendiri liat kelakuan". Dalam akun@brojabrooo, Ia tidak malu untuk mempermalukan diri sendiri dan mengundang 
gelak tawa dari followersnya. Unggahan ini pun mendapat balasan sebanyak 579 , retweets sebanyak 2.100, dan likes sebanyak 4.200 .

\section{The Law of Distinctiveness (Perbedaan)}

Hukum keunikan mengharuskan personal brand diungkapkan dengan cara yang unik. Dalam artian, penampilan personal brand harus berbeda dari penampilan kompetitornya. Sebagai konten kreator yang mengusung konsep humor, Jabro memiliki sejumlah kompetitor. Untuk membedakan dirinya dari yang lain, Ia kemudian membuat sejumlah konten dengan berbahasa Jawa Timur yang sukses mencuri perhatian warga net di Twitter. Disamping itu, Jabro juga sering menggunakan kata "Eiimmmm" dalam beberapa konten cuitan dan video yang ada di dalamnya.

Ide awal Jabro dalam mengangkat Bahasa Jawa dengan dialek Jawa Timuran sebagai tema untuk cuitannya di Twitter adalah agar konten yang Ia buat memiliki ciri khas yang tidak dimiliki oleh konten kreator lainnya. Jabro menginginkan agar Bahasa Jawa dengan dialek Jawa Timuran semakin dikenal oleh khalayak luas.

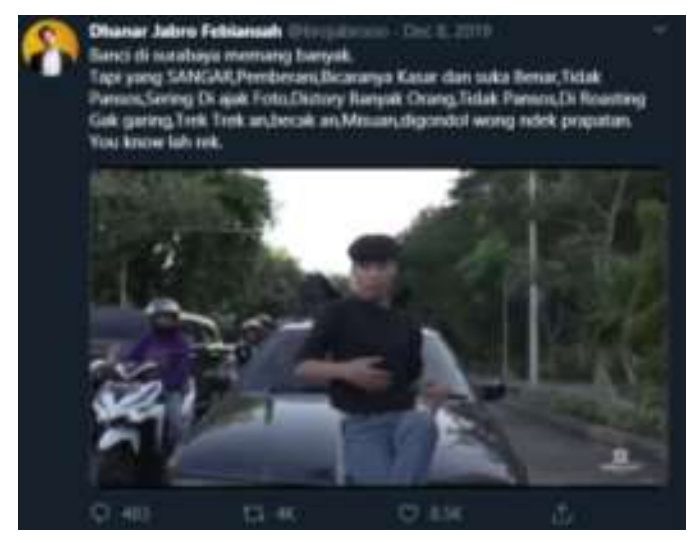

Gambar 19. Tangkapan Layar Tweet@brojabrooo pada 8 Desember 2019

(Sumber: twitter.com, 2020)

Konten video yang ditampilkan Jabro, ada beberapa yang memainkan peran yang berbeda. Ia lakukan dengan luwes dan sesuai dengan tuntutan cerita. Sebagai perempuan, Ia berdandan dengan pakaian perempuan, high heels, rambut palsu, kerudung, dan bersuara perempuan. Kemudian ketika berperan sebagai laki-laki, Jabro akan menyesuaikan penampilan, cara berbicara, dan dandanan yang sesuai dengna peran yang Ia bawakan.

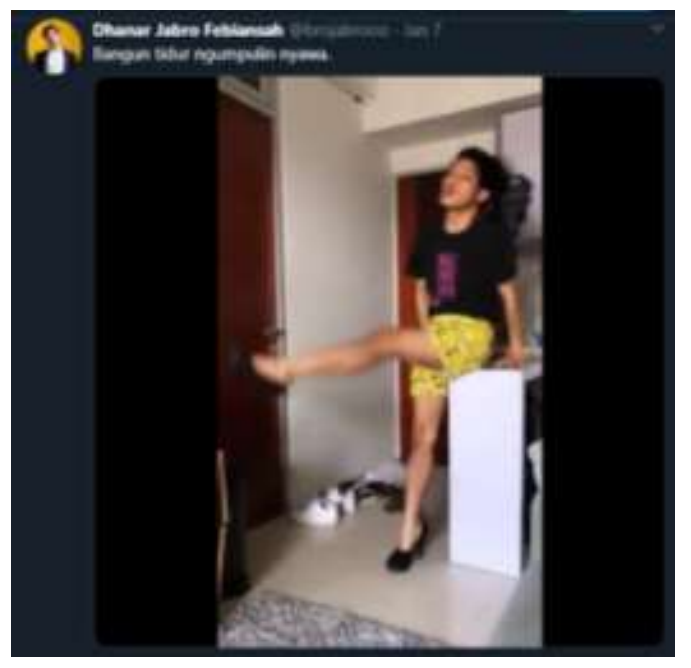

Gambar 20. Tangkapan Layar Tweet@brojabrooo pada 7 Januari 2020

(Sumber: twitter.com, 2020)

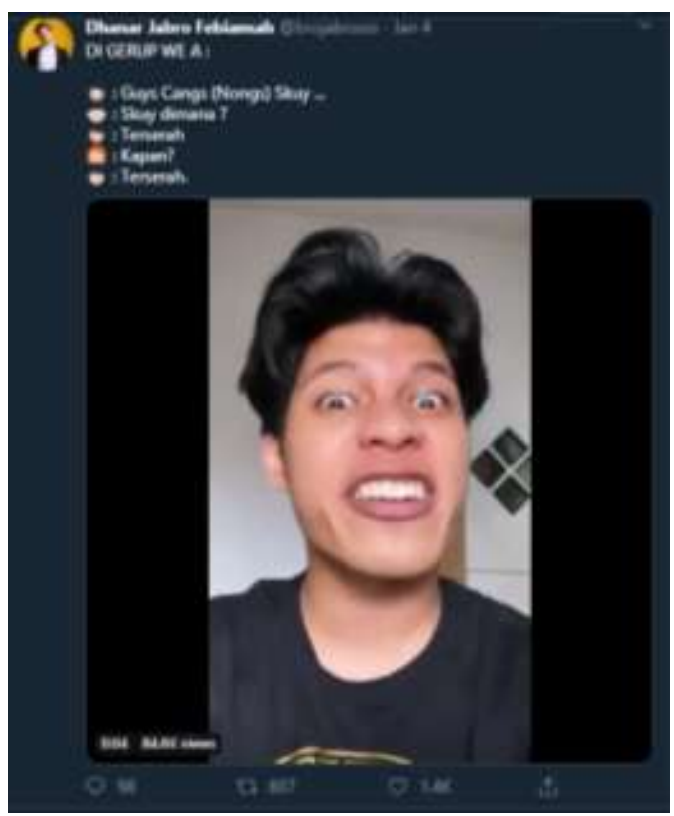

Gambar 21. Tangkapan Layar Tweet @brojabrooo pada 4 Januari 2020

(Sumber: twitter.com, 2020) 
Gambar 20 adalah berisikan tangkapan layar dari cuitan Jabro yang tertulis "Bangun tidur ngumpulin nyawa". Frekuensi Jabro dalam membuat konten video yang berisikan dirinya menari dengan menggunakan high heels cukup sering. Dalam satu bulan, sedikitnya 8 kali Jabro mengunggah tweet di Twitter yang berisikan konten video. Video tersebut diantaranya berisi tentang tarian yang dilakukan oleh Jabro, video parodi, dan video receh yang mengundang tawa. Cuitan yang terdapat unggahan video di dalamnya selalu mendapatkan engagement yang tinggi dari pengguna Twitter, baik dalam jumlah viewers yang tinggi maupun likes yang banyak seperti pada gambar 21 .

\section{The Law of Visibility (Kenampakan)}

Seseorang dikatakan berhasil dalam membangun personal branding jika Ia secara konsisten menampilkan dirinya. Seseorang harus melakukan personal branding secara terus-menerus sehingga personal branding orang tersebut menjadi dikenal. Secara konsisten dan sadar, Jabro mempublikasikan dirinya dalam bentuk teks, foto, maupun video. Jabro mempublikasikan dirinya sebagai seorang konten kreator yang memiliki selera humor yang tinggi dan mengangkat bahasa lokal yakni bahasa Jawa Timur. Hal ini dilakukan oleh Jabro dengan konsistensi yang cukup tinggi.

Selama September 2019 hingga Januari 2020, Jabro hampir setiap hari melakukan cuitan setidaknya satu kali dalam sehari. Hal ini dilakukan agar Jabro semakin dikenal oleh warga net. Gambar 22 dan 23 menunjukkan bahwa Jabro melakukan beberapa kali unggahan cuitan dalam satu hari.

Graciyal \& Viswam (2018) menyatakan bahwa media sosial adalah cerminan dari kepribadian kita. Media sosial dapat menggambarkan kesukaan, opini, dan bagaimana orang melihat sosok kita. Media sosial selain tempat berekspresi juga menjadi tempat bebas menyampaikan opini/konten. Media sosial menjadi platform alternatif untuk mengekspresikan diri. Oleh karena itu, apapun yang kita unggah secara online dinilai merepresentasikan apa yang menjadi ciri khas kita dengan cukup akurat (Orehek \& Human, 2016). Sejalan dengan pendapat-pendapat tersebut, Jeff Bezos founder dari Amazon juga berpendapat bahwa personal branding secara sederhana dipahami sebagai bagaimana Anda merepresentasikan diri ke orang lain. Bagaimana seseorang ingin dilihat atau dikenal oleh orang lain yang membuat seseorang terlihat unik dan berbeda dari yang lain.

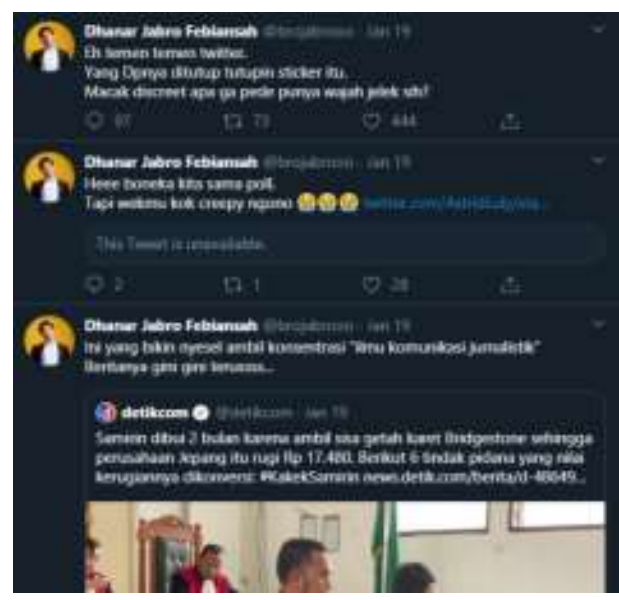

Gambar 22. Tangkapan LayarTweet@brojabrooo pada 19 Januari 2020

(Sumber: twitter.com, 2020)

\section{The Law of Unity (Kesatuan)}

The Law of Unity atau kesatuan yang dimaksud dalam pembentukan personal branding adalah kehidupan pribadi yang sejalan dengan apa yang dibentuk dalam personal branding seseorang. Dalam konteks penelitian ini, Jabro berusaha menyinergikan kehidupan kesehariannya dengan apa yang Ia tampilkan dalam media sosial. Segala hal yang terjadi dalam kesehariannya merupakan sebuah realita pengalaman personalnya yang sejalan dengan apa yang dia bagikan melalui akun media sosialnya. Oleh karena itu, terbentuklah kesatuan yang bersinergi dan tidak saling bertolak belakang. Hal ini pada akhirnya dapat memperkuat citra yang muncul pada mata khalayak atas personal branding yang dilakukan oleh Jabro. 
The Law of Unity ditampilkan Jabro dengan menempatkan dirinya sebagai seorang konten kreator yang tidak mengekslusifkan dirinya. Jabro berusaha agar dirinya dipandang sebagai konten kreator yang juga sebagai pribadi manusia pada umumnya. Salah satunya adalah cuitan yang ada pada gambar 23 yang membahas tentang skincare. Jabro membuat cuitan yang menyatakan bahwa dirinya kesal dengan teman laki-laki yang lain yang hanya mencuci muka dengan sabun batangan dan wajahnya glowing. Sedangkan dirinya harus menggunakan skincare beberapa layer untuk mendapatkan hasil serupa.

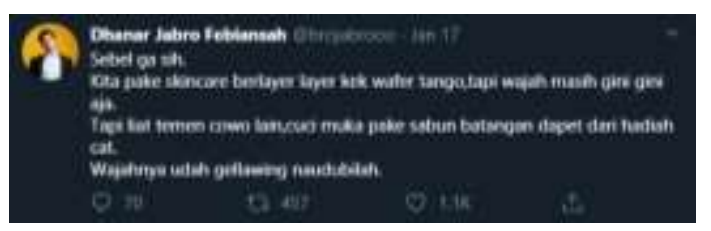

Gambar 23. Tangkapan Layar Tweet@brojabrooo pada 17 Januari 2020

(Sumber: twitter.com, 2020)

\section{The Law of Persistence (Keteguhan)}

Dalam membangun personal branding, seorang konten kreator harus berproses. Proses ini dapat memakan waktu yang tidak sebentar. Dalam proses ini Jabro membutuhkan waktu yang cukup lama sehingga membutuhkan keteguhan terhadap personal branding yang dibentuk sejak awal tanpa ada ragu untuk mengubahnya. Apabila hal tersebut terjadi, maka akan bertolak belakang dengan prinsip konsistensi yang sudah dijelaskan di awal.

Sedari awal, Jabro telah membangun personal branding dirinya sebagai seorang konten kreator komedi dengan Bahasa Jawa Timuran. Hal ini terlihat dalam cuitannya sebagai berikut. Jabro kemudian viral melalui video lypsinc yang menirukan Agnes Monica.

Jabro membeberkan rahasia dapur dari konten video yang selama ini dia buat dalam beberapa cuitan berikut. Pada gambar 24, Jabro mengunggah video yang dibuatnya sekitar 2 tahun lalu dengan peralatan yang seadanya. Melalui cuitan ini, Jabro berterima kasih atas apresiasi followersnya jika terhibur dengan konten video yang dibuatnya. Konten video yang ada dalam cuitan ini telah ditonton sebanyak lebih dari 83.100 pengguna, dikomentari sebanyak 339, mendapat retweet sebanyak 792, dan disukai lebih dari 1.900 pengguna.

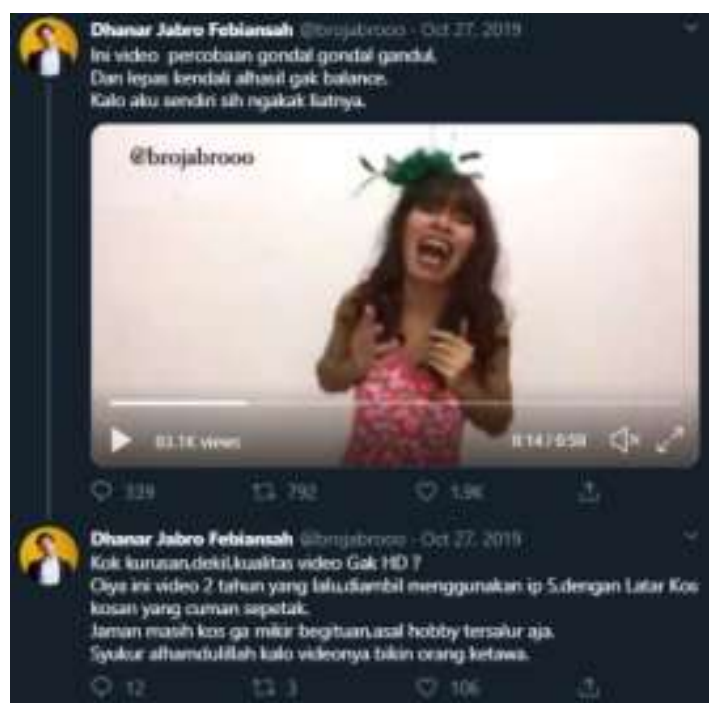

Gambar 24. Tangkapan Layar Tweet@brojabrooo pada 27 Oktober 2019

(Sumber: twitter.com, 2020)

Keteguhan akun@brojabrooo dalam membuat cuitan yang berisi video telah dilakukan sejak dahulu. Berikutadalah beberapa hasil tangkapan layar yang membuktikan bahwa Jabro konsisten dengan konten video lypsinc, cover dance, dan video receh.

\section{The Law of Goodwill (Maksud Baik)}

Pada prinsipnya, seseorang dapat dipandang positif oleh khalayak dan bertahan lama apabila sudah memiliki personal brand. Pandangan positif yang datang dari khalayak tersebut tidak datang dengan sendirinya, melainkan dari nilai-nilai yang sudah ditanamkan oleh pelaku personal branding.

Personal branding seorang konten kreator dalam media sosial dapat memiliki pengaruh yang signifikan bagi followers dan warga net lainnya. Untuk itu, agar dipersepsikan secara baik oleh warga net, seorang konten kreator harus berhati-hati dalam menyampaikan pesan. 
Dalam cuitan yang dilakukan oleh akun Twitter @brojabrooo, Ia juga membawa pesan positif kepada warga net. Diantaranya ditunjukkan dalam cuitan berikut.

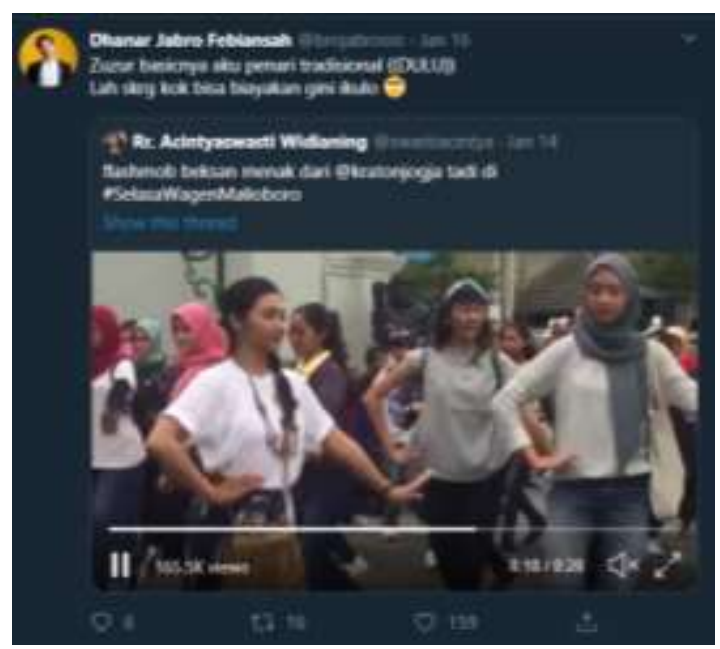

Gambar 25. Tangkapan Layar Tweet@brojabrooo pada 16 Januari 2020

(Sumber: twitter.com, 2020)

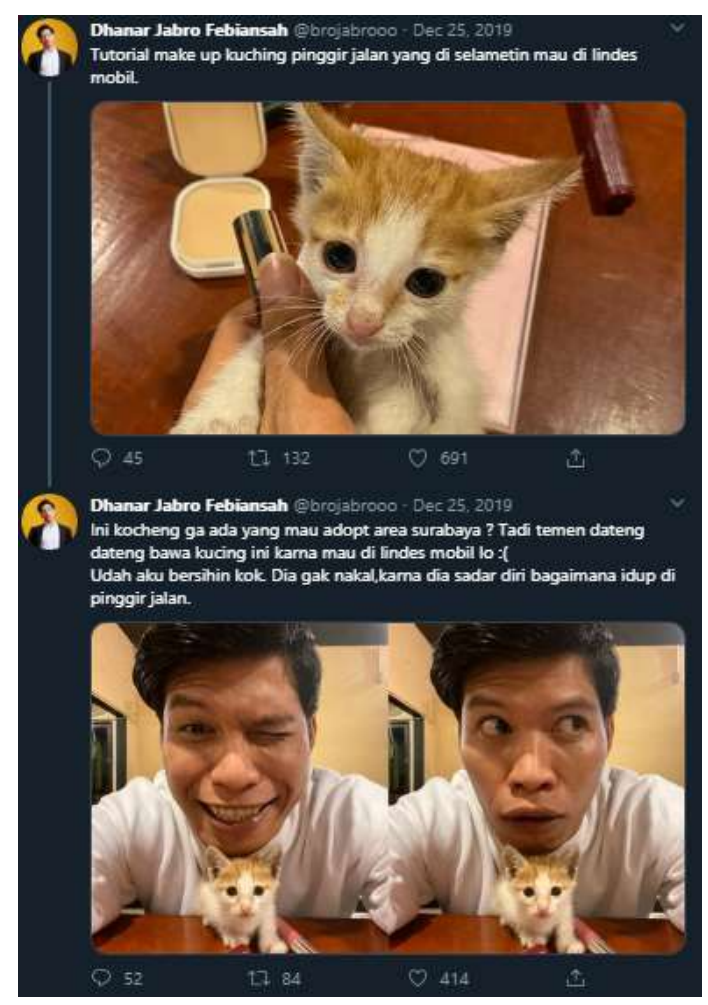

Gambar 26. Tangkapan Layar Tweet@brojabrooo pada 25 Desember 2019

(Sumber: twitter.com, 2020)

Pada gambar 25, Jabro ingin menunjukkan kekagumannya terhadap acara flashmob
Beksan Menak yang diadakan oleh Kraton Jogja. Sebagai seorang konten kreator yang mencintai Bahasa Jawa dan budaya Jawa, Ia terheran dengan acara tersebut. Hal ini dibuktikan dengan kalimat yang tertulis dalam cuitan dan emoticon yang digunakan.

Adapun pada gambar 26, Jabro menunjukkan kecintaannya terhadap kucing. Ia menceritakan tentang kronologi kucing yang akan terlindas oleh mobil. Kemudian Ia menawarkan kepada followersnya dan warga net untuk mengadopsi dan merawat kucing tersebut.

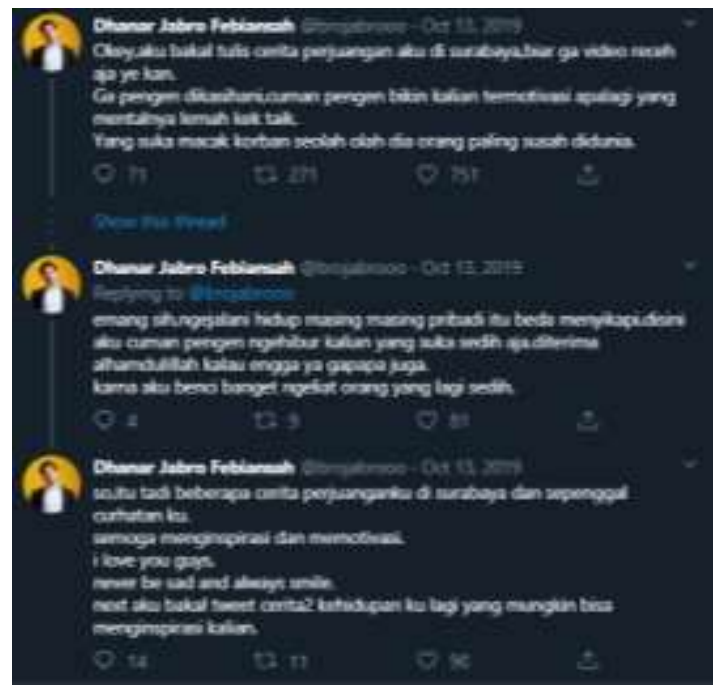

Gambar 27. Tangkapan Layar Tweet@brojabrooo pada 13 Oktober 2019

(Sumber: twitter.com, 2020)

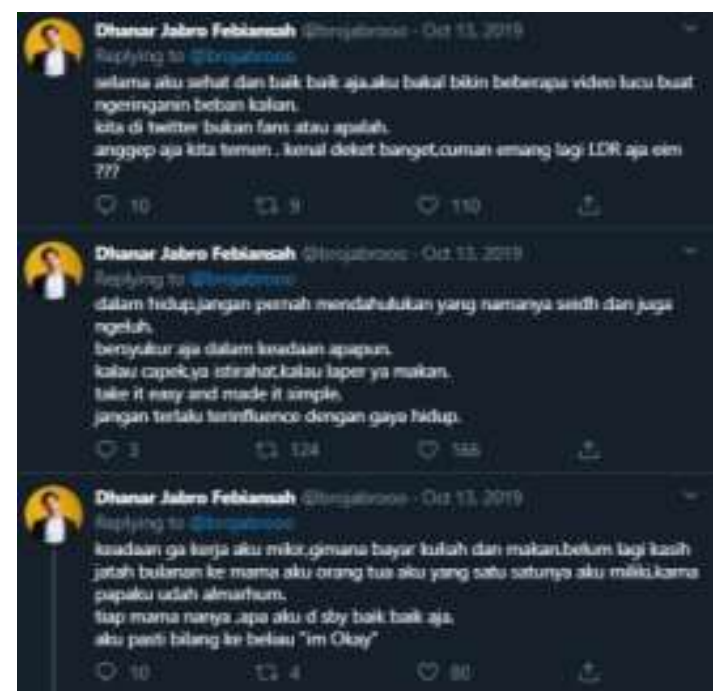

Gambar 28. Tangkapan Layar Tweet@brojabrooo pada 13 Oktober 2019

(Sumber: twitter.com, 2020) 
Maksud baik Jabro dalam akun @ brojabrooo ditunjukkan dalam beberapa cuitannya. Diantaranya adalah pada gambar 27 dan 28, Jabro berkisah tentang perjuangan dirinya di Surabaya dalam sebuah utas. Utas ini pun disukai oleh 751 pengguna Twitter dan mendapat retweet sebanyak 271. Utas ini bertujuan untuk memotivasi pengikutnya dan pengguna Twitter lainnya.

Utas adalah hal yang jarang dilakukan oleh akun@brojabrooo sehingga ketika dirinya membuat utas yang menceritakan tentang kehidupan, pengguna Twitter menjadi penasaran dengan cerita tersebut. Hal ini terlihat dari adanya komentar dalam setiap cuitan yang ada dalam utas tersebut.

Dalam kesempatan lain, @brojabrooo pernah menuliskan bahwa saat SMP dia pernah ditanya tentang cita-citanya setelah lulus. Ia pun menjawab ingin menjadi entertainer dan ditertawakan oleh teman sekelasnya. Jabro pun kini dapat membuktikan cita-cita tersebut. Dilengkapi dengan sebuah foto di depan salah satu stasiun televisi swasta, Ia berpose dengan senyum lebar. Unggahan ini pun disukai oleh lebih dari 1.900 pengguna.

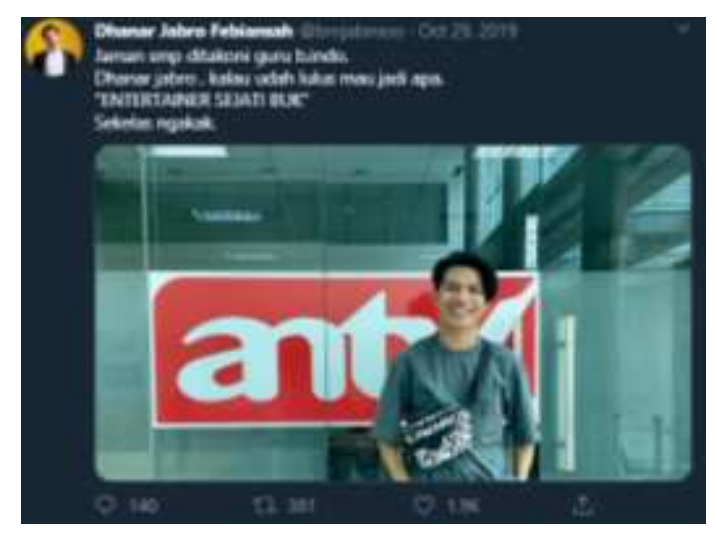

Gambar 29. Tangkapan LayarTweet@brojabrooo pada 29 Oktober 2019

(Sumber: twitter.com, 2020)

Berdasarkan analisis yang telah dilakukan, proses pembentukan personal brand melalui media sosialTwitter akun@brojabrooo adalah sebagai berikut.

\section{SIMPULAN}

AkunTwitter@brojabrooo melakukan kegiatan personal branding. Proses pembentukan personal branding dengan menggunakan media sosial Twitter diawali dengan pemenuhan terhadap kriteria Authentic Personal Branding yang dibutuhkan seseorang untuk dapat melakukan personal branding. Kriteria yang digunakan dalam penelitian ini adalah kriteria yang dikemukakan oleh Peter Montoya yaitu terdapat 8 kriteria.

Peneliti menemukan 8 konsep utama dalam membangun personal branding sesuai dengan apa yang dikemukakan oleh Peter Montoya (2002). Delapan konsep tersebut adalah spesialisasi (the law of specialization), kepemimpinan (the law of leadership), kepribadian (the law of personality), perbedaan (the law of distinctiveness), kenampakan (the law of visibility), kesatuan (the law of unity), keteguhan (the law of persistence), dan nama baik (the law of goodwill). Delapan konsep utama ini menunjukkan bahwa Jabro membangun personal branding sebagai seorang konten kreator melalui Twitter. Hal tersebut terlihat dari cuitan Jabro yang berisikan berbagai macam konten yang sebagian besar didominasi oleh foto dan video tentang dirinya. Personal branding yang dibangun oleh Jabro adalah seorang konten kreator yang ingin menghibur netizen dan konsisten menggunakan Bahasa Jawa Timuran.

Saat konten kreator membangun personal brand, visi misi merupakan suatu hal yang penting. Hal ini dikarenakan ketika seorang konten kreator melakukan proses personal branding, maka konten kreator tersebut juga harus menampakkan kepribadian aslinya. Kepribadian asli yang sesuai dengan perilaku kesehariannya di dunia nyata. Apabila kepribadian antara dunia maya dan nyata tidak bersinergi, dikhawatirkan ikatan emosional diantara konten kreator dan pengikutnya tidak akan terjadi.

Secara spesifik, seorang konten kreator juga harus dapat menjaga konsistensi dalam 


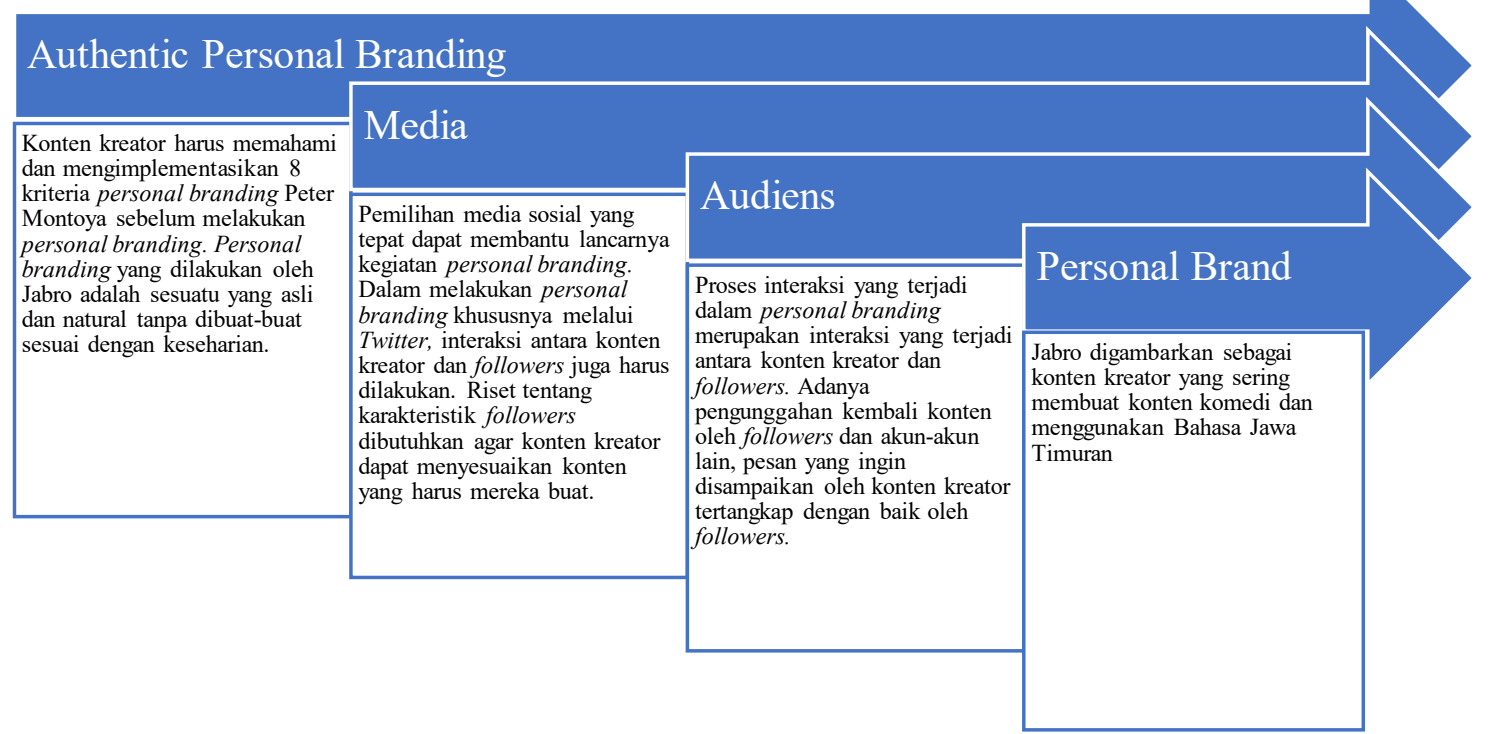

Gambar 30. Pembentukan Personal Branding Jabro dalam akun Twitter@brojabrooo (Sumber: Hasil Penelitian, 2020)

membentuk personal brand di media sosial. Konsistensi sangat penting mengingat konten kreator membentuk persepsi dalam media sosial yang Ia gunakan. Dalam konteks ini, Twitter yang digunakan oleh Jabro membentuk persepsi tentang dirinya dihadapan followers dan warga net. Persepsi ini akan berpengaruh pada personal brand yang Jabro bangun.

\section{DAFTAR PUSTAKA}

Creswell, J. W. (2012). Qualitative Inquiry and Research Design, Choosing Among Five Traditions. California: Sage Publications.

Graciyal, D.G. \& Viswam, D. 2018. Freedom of Expression in Social Media: A Political Perspective. International Journal of Multidisciplinary, Vol. 3 (1), January 2018.

Hermawan, K. (2008). Seri 9 Hermawan Kertajaya on Marketing Mix. Marketing Mix.

Mcnally, D. \& Speak, Karl D. 2004. Be Your Own Brand. Jakarta: PT Gramedia Pustaka Utama.

Montoya, P. (2002). The Personal Branding
Phenomenon. Nashville: Vaughan Printing.

Montoya, P. \& Vandehey Team. (2004). Strategic Personal Branding. Mumbai: Jaico Publishing House.

Montoya, P. (2009). The Brand Called You. New York: McGraw Hill.

Narida, M. G. (2019). “Kang Pisang” : Personal Branding Putra Bungsu Jokowi dalam Media Microblogging. JCOMMSCI Journal of Media and Communication Science, 2, 17-33.

Nasution, S. (2002). Metode Penelitian Naturalistik Kualitatif. Bandung: Tarsito.

Orehek, E. \& Human, L. J. 2016. SelfExpression on Social Media: Do Tweets Present Accurate and Positive Portraits of Impulsivity, Self-Esteem, and Attachment Style? Personality and Social Psychology Bulletin, Vol. 43 (I), 60-70.

Rachmawati, D., \& Nurhajati, L. (2019). Komunikasi Media Online Pengusaha Milenial dalam Membangun Personal Branding di Era Digital. 
Metacommunication: Journal of Communication Studies. https://doi. org $/ 10.20527 / \mathrm{mc} . v 4 i 1.6357$

Rampersad, H. K. (2008). A New Blueprint for Powerful and Authentic Personal Branding. Performance Improvement. https://doi.org/10.1002/pfi.20007

Shimp, T. A. (2004). Advertising, Promotion and Supplemental Aspects of Integrated Marketing Communication. Journal of Marketing Communications. https://doi. org $/ 10.1080 / 1352726042000250498$

Vollmer, C. (2017). Entertainment and Media Trends. Diakses dari strategyand.pwc. com:https://www.strategyand.pwc. com/trend/2017-entertainment-andmedia-trends

We Are Social. 2017, January 24. Diakses dari wearesocial.com:http://wearesocial. com/blog/2017/01/digital-in-2017global-overview

Wibowo, A., \& Rusdi, F. (2019). Analisis Personal Branding Youtuber Gim: (Studi Fenomenologi Michael Souw). Prologia. https://doi.org/10.24912/ pr.v3i1.6132

Yusuf, K. (2019). Budaya Jawa dalam Memperkuat Personal Branding. Konvergensi, 01(01), 1-18. 